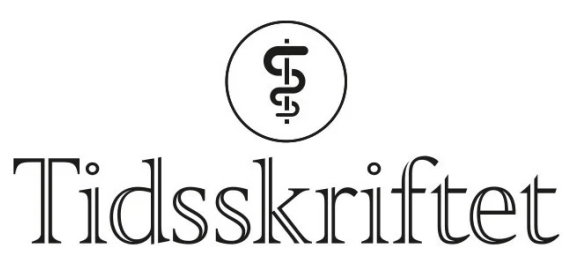

DEN NORSKE LEGEFORENING

\title{
Er warfarinæraen over?
}

\author{
BREV TIL REDAKTØREN
}

\section{HELGE STORMORKEN}

Helge Stormorken (f. 1922) er professor emeritus.

Ingen oppgitte interessekonflikter.

Email: hestormo@frisurf.no

Takk til Åsmund Reikvam for leder om antikoagulantia i Tidsskriftet nr. 23-24/2012 (1). Jeg synes at professor Frank Brosstad og kollegers meget nyttige minibøker over indikasjoner og dosering av antikoagulantia burde vært med i innlegget (2). Etter mitt syn er de meget nyttige - om ikke lenger for meg.

Publisert som rask respons på nett 17.12. 2012

\section{LITTERATUR \\ 1. Reikvam Å. Er warfarinæraen over? Tidsskr Nor Legeforen 2012; 132: 2583. [PubMed] \\ 2. Brosstad F. Legens råd til pasienter som behandles med Marevan. 5. utg. Asker: Nycomed, 2007.}

Publisert: 19. februar 2013. Tidsskr Nor Legeforen. DOI: 10.4045/tidsskr.13.0119

(C) Tidsskrift for Den norske legeforening 2023. Lastet ned fra tidsskriftet.no 26. april 2023. 